Article

\title{
Gatekeeping Access: Shea Land Formalization and the Distribution of Market-Based Conservation Benefits in Ghana's CREMA
}

\author{
Mengina Gilli ${ }^{1,2}$, Muriel Côte ${ }^{3, *}$ and Gretchen Walters ${ }^{4,5,6}$ \\ 1 Department of Geography, University of Zurich, Winterthurerstrasse 190, 8057 Zürich, Switzerland; \\ mengina.gilli@zhaw.ch \\ 2 Institute of Natural Resource Sciences, Zurich University of Applied Sciences, Center da Capricorns, \\ 7433 Wergenstein, Switzerland \\ 3 Department of Human Geography, Lund University, Sölvegatan 10, 22362 Lund, Sweden \\ 4 Global Forest Program, International Union for Conservation of Nature, Rue Mauverney 28, \\ 1196 Gland, Switzerland; gretchen.walters@unil.ch \\ 5 Department of Anthropology, University College London, Gower Street, London WC1E 6BT, UK \\ 6 Faculté de Géosciences et Environnement, Institut de Géographie et Durabilité, Université de Lausanne, \\ 1015 Lausanne, Switzerland \\ * Correspondence: muriel.cote@keg.lu.se
}

Received: 11 September 2020; Accepted: 26 September 2020; Published: 29 September 2020

\begin{abstract}
Community Resource Management Areas (CREMAs) in Ghana combine conservation and development objectives and were introduced in the year 2000. In some cases, they have connected collectors of shea (Vitellaria paradoxa) nuts with certified organic world markets, which can be understood as a 'market-based' approach to conservation. This paper examines how the benefits of this approach are distributed and argues that shea land formalization is crucial to this process. It makes this argument by drawing on interviews within two communities bordering Mole National Park. One community accepted to engage with, and benefitted from this approach, while the other did not. The paper analyzes narratives from different actors involved regarding why and how the market-based approach was accepted or rejected. It shows that, contrary to the neoliberal principles that underlie market-based conservation, a utility maximization rationale did not predominantly influence the (non-)engagement with this conservation approach. Instead, it was the history of land relations between communities and the state that influenced the decisions of the communities. We highlight the role of traditional authorities and NGOs brokering this process and unpack who in the communities profited and who was left out from benefits from this market-based conservation initiative.
\end{abstract}

Keywords: community based natural resource management; Ghana; formalization; shea; certification; conservation; market-based conservation

\section{Introduction}

Community-Based Natural Resource Management (CBNRM) and Integrated Conservation and Development Projects (ICDPs) were adopted in many countries in the 1980s and 1990s to combine conservation and development objectives [1]. These models entail the idea that participation in conservation can be ensured through increasing the economic benefits that participants obtain from conservation-related activities, such as ecotourism, or the trade of natural resources [2-5]. The inclusion of economic incentives at the core of conservation has gained further ground, shifting towards what has been called 'market-based' approaches to conservation [6,7]. In this paper, we examine the role that land formalization - or the 'recognition and inscription by the state of rights and conditions of 
access within specific boundaries' [8]—plays in the distribution of access to benefits from market-based conservation around Mole National Park in northern Ghana.

Our research is based on the case of the Ghanaian model of CBNRM called Community Resource Management Areas (CREMAs). This model is typically associated with protected areas or forest reserves. It encourages local communities to engage in a variety of environmental projects, including connecting female shea collectors to the global certified organic shea nuts markets, as is the case in this paper. We compare access to shea trade benefits of a community that accepted the CREMA model, to another that rejected it. During fieldwork, it became clear that the community that accepted the CREMA had access to the benefits-however marginal-from being connected to the global organic shea markets, while the community that rejected the CREMA did not. The process of land formalization in the CREMA was found to be key to understanding how market-based conservation benefits were thereby distributed: land formalization was interpreted by the latter community as a form of dispossession by the state, similar to that which had occurred several decades earlier, during the creation and successive expansions of the neighboring Mole National Park. With this case, we argue that the neoclassical economic assumptions underlying market-based conservation $[9,10]$ do not hold: the potential added economic benefits are not enough to understand how potential participants decide to engage in this conservation approach; social historical land relations also mediate that engagement. In this paper, we examine what these relations look like in each case, through the negotiated encounter of actors who broker shea land formalization in the name of the state-namely traditional chiefs and an environmental NGO - which helps us understand some of the conditions under which market-based conservation benefits are distributed. We call this process 'gatekeeping access'.

CREMAs were initiated in 2000 by Ghana's Wildlife Division [11], as part of the CBNRM trend, as well as from a second wave of decentralization reforms [12]. CREMAs are often located on the periphery of protected areas or forest reserves and are meant to foster rural development and conservation through a participatory approach $[3,13]$. Here we focus on the area bordering the Mole National Park, and specifically on the case of the Murugu-Mognori CREMA that was developed in the 2000s [14], and the Yazori-Kaden CREMA that was rejected by residents in the same period. In the former CREMA, several economic activities were fostered, such as bee keeping, animal husbandry, ecotourism, and the marketing of certified organic shea (Vitellaria paradoxa) nuts, which we discuss in this paper.

Shea has been part of regional and local trade for centuries in Ghana, and it was also part of colonial trade efforts between 1912 and the 1930s, until shea was disfavored for groundnuts; only in the 1990s did shea become part of global trade again [15]. Today, women continue to collect shea nuts from the savanna and farms, process them into butter and soap, and/or sell them as raw nuts [16]. Shea nuts are an important non-timber forest product (NTFP) for many women and their families, both for domestic use and cash income [17-19]. Since shea became an important global commodity, its value chain has become segmented into two markets: $90 \%$ of shea export is used as an industrial fat, mainly as a cacao butter equivalent, and the other $10 \%$ is used as raw material for cosmetics $[17,20]$.

The certified market for cosmetics is a lucrative niche, which became connected to conservation in our study area. Shea butter extraction accounts for a significant share of the, especially female, labor force in the area (and elsewhere), but is understood by conservationists to operate under a 'first-come, first-served' regime that is detrimental to conservation [14]. Land use and management rules and rights are largely informal in Ghana, and the Murugu-Mognori CREMA brought shea use and access rights into formal law-what we call 'shea land formalization' - as a prerequisite to connecting rural women to a certified organic shea trading company. With this set up, only communities that agreed to form a CREMA are able to benefit from the added economic value of certified organic shea trade. So why did Kaden refuse to be part of the CREMA, even though the CREMA model promised to bring them benefits? Also, how did Murugu, who accepted the CREMA, benefit from accessing the certified organic shea market? In other words, our overall question is how did the distribution of market-based conservation benefits take place? In this case, we show that the moment of land formalization pertaining to the CREMA model was key, specifically through the negotiated encounters 
of those who broker land formalization-in this case traditional authorities and a NGO. We call these brokers 'gatekeepers', drawing on work in the anglophone and francophone anthropology of development work on the role of development brokers and translators [21,22].

We situate our contribution within scholarship that highlights contradictions within market-based approaches to conservation $[10,23]$. Some of this scholarship has pointed out that a focus on the market as a mediator of environmental conservation and governance more widely has unevenly distributed the burdens and the benefits of this approach [9]. Others have further shown that the 'market' cannot be understood without taking into account the social relations of cooperation and exclusion that connect and disconnect actors [24]. We build on this scholarship to suggest that when market-based conservation includes the trade of natural resources, it involves the reshaping of property rights, here in shea land formalization, which is a key moment when relations of cooperation and exclusion become articulated with conservation. In this process, we suggest paying more attention to the relations between these actors, such as the paternalistic and patriarchal ones emphasized in feminist work [24,25], which are key to the way that cooperation and exclusion take place.

We base our analysis on ethnographic fieldwork conducted by the first author for two months in 2017, which focused on understanding the different narratives of CREMA acceptance and rejection as well as differentiated shea market benefits. It was strengthened by the last two authors' research experience with the history and conservation dynamics in the region. After describing our methodology, we present the study area's history of land control. We then present our analysis in two empirical sections. The first shows how the enrolment of communities in the CREMA model goes beyond the narrow economic market logic that underlies market-based conservation. Their enrolment instead involves the negotiated encounter between traditional authorities and a NGO, and is mediated by the tense state-society history around the creation of Mole National Park, not unlike what is experienced in other communities with similar histories with parks [26]. The second examines the way these negotiated encounters map onto perceptions of benefits from the shea trade in each community. It shows that in Murugu, where the CREMA was accepted, women were able to benefit, but only marginally, from access to the certified organic market niche, whereas in Kaden residents felt excluded from these promises. It is based on these perceptions that we argue that the negotiated encounter between traditional authorities and the NGO has played the role of 'gatekeeping access' to the market-based conservation benefits of the shea trade. We conclude by highlighting the argument's significance that we see in relation to literature related to market-based conservation and to conservation practice.

\section{Materials and Methods}

Data for this paper was collected during fieldwork conducted by the first author between September and October 2017 in the communities of Murugu and Kaden in Ghana. Semi-structured qualitative interviews were the main method used in this study. Different stakeholders were interviewed to triangulate the data. The sampling strategy followed Bolwig's et al. [27] framework for horizontal value chain analysis [24]. The combination of horizontal and vertical elements in this framework enables researchers to include gender issues that arise through changes in the value chain. It also gives a better understanding concerning the inclusion and exclusion of people in the value chain. Interviews included chain actors (women participating in the certification project), external actors (NGO staff, traditional authorities, CREMA board members, certification companies, park management, researchers), excluded actors (women, who did not want to or were not able to participate) and non-participants (youth, husbands of participants). The interviews focused on eliciting the diversity of narratives regarding why the CREMA was either accepted or rejected by these communities. Each interview was recorded, transcribed, and coded with the software MAXQDA.

The data analysis quickly suggested that the acceptance and rejection of the CREMA by the two communities were explained differently by different actors. Our analysis here does not focus on drawing out one single 'true' story, but rather 'patterns of truth' through the several narratives used to explain the same event [28]. These patterns of truth inform us, from a Foucauldian perspective, 
about the 'set of unspoken rules which govern, control, and produce knowledge in a culture.' [28]. It is in the context of this analysis that historical land relations came across as a key issue in the land formalization process.

Some issues influenced data collection. Firstly, access to the study area was initially provided by the NGO that helped initiate the creation of the CREMA in Murugu, so access to informants in Kaden was more difficult than in Murugu, which had a good working relationship with the NGO. Access to the NGO was also provided by an initial contact with an international organization which supports the NGO's work, but only marginally financed some of its activities, so we assumed that the narrative from the interviews with NGO staff was not significantly shaped by that organization. Given the sensitivity of the topic in Kaden, who had refused the CREMA, individual interviews were used, in addition to focus group discussions; the individual interviews created trust. The lack of language skills in Hanga was also an issue: it required working with a translator. Patriarchal relations influenced data collection with women, and to address this, three translators were used: two male and one female.

\section{Results}

\subsection{Contextualising the Case Study}

Conservation, Displacement, and Shea Land Formalization in the Mole Area

The Murugu-Mognori CREMA is situated in the savannas of the Mole area of northern Ghana that has seen several waves of displacements (Figure 1), at least since the British colonial era. It is largely occupied by the Gonja group, whose Kingdom became established in northern Ghana in the late 16th century [29], through conquest over acephalous societies [30]. In the 1890s, a Gonja civil war occurred, as well as battles with colonial forces [31] with a resulting depopulation due to the civil war, as attested to by old village sites in Mole National Park [32] and nearby archaeological ruins [29]. During colonial rule, Ghana's Northern Territories were the subject of many agricultural and trade initiatives, of which shea was a focus from 1912 to the 1930s [15], until it was outpaced by interest in other crops such as groundnuts. In the Damongo area (just south of Mole National Park), the large Gonja Development Project occurred from 1948-1957; this project was located there because the British colonial government considered that the area had been vacated by slave raiding and tsetse infestation, leaving the area 'vacant', and so ready for agricultural development [33]. This project invited an influx of laborer and attempted but failed to reorganize agricultural labor, including resettling entire villages to the area, and subverting the roles of customary authorities [33]. The North Mamprusi Forestry Conference held in Navrongo in November 1947, which led to the creation of the GDC, adopted a resolution concerning land planning in the area. Although this resolution was later ignored, it brought about the eventual gazettement of headwater protection reserves in the Northern Territories, which had been previously proposed by the Forestry Department Ten Year Plan [34].

In this same area, in the 1930s, the colonial government created a hunting reserve, the precursor to Mole National Park. Between 1948 and 1957, at the same time as the Gonja Development Project, forest protection in the savanna zone of Ghana was undertaken as part of a land use planning exercise; in some places, a Reserve Settlement Commission was set up to protect community rights of access and to exclude existing farms from reserve areas [12]. ${ }^{1}$

The first president of Ghana, Kwame Nkrumah, established Mole Game Reserve in 1958 just after independence in 1957, and it today represents the largest, biologically diverse savannah ecosystem in Ghana [35]. The Reserve enclosed Gonja hunting grounds, hunting camps, and six villages. In 1964, 500 people from five communities in the southern part were resettled outside of the reserve by governmental authorities [36]. In 1971, the reserve was legally gazetted as a national park, and a

1 It is not known if such a Commission was established for the creation of Mole National Park or the preceding reserve. 
further extension was made. Between 1979 and 1985, the park suffered from Ghana's economic decline. Its infrastructure was in a poor condition and poaching was increasingly perceived as a problem by the government during this time. In the 1990s, Mole National Park gained support from international organizations [36]. In 1992, the park was again expanded, which resulted in the eviction of one last community [36]. Today, 33 communities, about 40,000 people, surround Mole National Park, coming from three traditional areas (Wa, Gonja, and Mamprusi) [37].

The eviction of communities for the creation and successive expansions of Mole National Park caused mistrust and resentment against governmental institutions, which continues today [14,38]. The two communities that were visited for this study, Murugu and Kaden, both lost agricultural land, sacred places, and hunting grounds, which restricted their livelihood activities [38]. Participation of the local communities in the park's development was not common at the time of its establishment. Traditional chiefs were involved to some extent in the eviction process, but the concept of a 'park', was difficult to explain (ex-NGO staff, Damongo, interview, 19 October 2017). The evictions of people from Mole National Park therefore made the relationship between communities and the park, (and by extension, the state) tense.

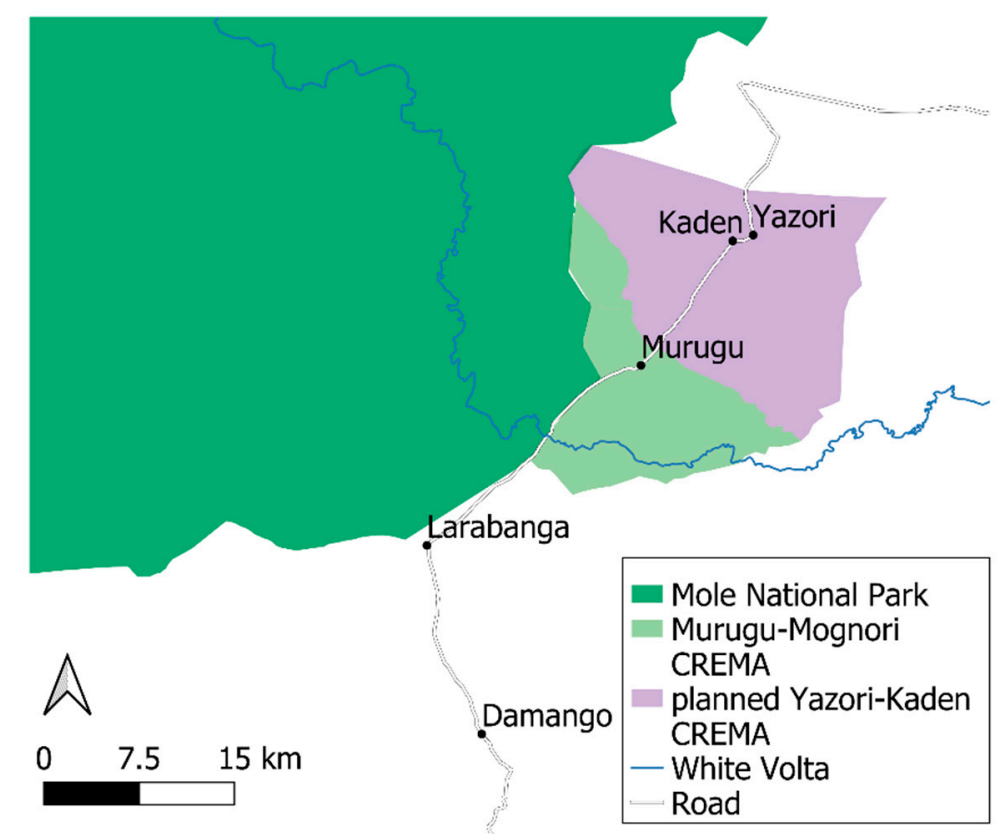

Figure 1. Study area (Sources: A Rocha Ghana and IUCN Ghana, 2014; Open Street Map. Map Illustration: Mengina Gilli.).

Since the 1980s, many participatory resource management initiatives have been introduced in different places throughout the world, as a response to similarly tense relationships in other conservation areas $[39,40]$. In Ghana, the Wildlife Division realized that exclusive conservation was neither fruitful for their relationship with the communities, nor for reaching conservation goals [35]. When a new Forest and Wildlife Policy was established in 1994, it contained a Community and Collaborative Wildlife Management framework, which resulted in the elaboration of CREMAs in 2000 [35]. To some extent then, CREMAs have been used as a tool to reduce the tension between surrounding communities and park state authorities. In 2018, there were five CREMAs bordering Mole National Park, and they seek to 'build the capacity of, and provide incentives for, local communities to sustainably manage and conserve natural resources in and outside the Park' [14]. The CREMAs to some extent aim to reduce these tensions by allowing surrounding communities to define resource regulations themselves, define user rights, and support natural resource-based income-generating activities.

In the study area, the planned income activities included tourism and the commodification of natural resources, especially shea. This has taken shape through the work of one NGO that linked 
CREMA communities with a certified shea trading company. This has worked in the village of Murugu, which became part of the Murugu-Mognori CREMA, established in 2008, and is $237 \mathrm{~km}^{2}$ in size. By contrast, it did not work in the village of Kaden, situated around 12 kilometers away from Murugu, and where the planned Yazori-Kaden CREMA was rejected by residents [11]. The reasons for the rejection of the CREMA there are manifold, and we explore them as part of our analysis in further sections.

In Northern Ghana, both the state and traditional authorities regulate natural resource use, including shea. The state is formally responsible for distributing resource ownership and traditional authorities hold the land in trust for the people [41]. Formally, the state owns shea trees, while traditional authorities informally regulate access to trees. Their jurisdictions overlap and sometimes come into tension when it comes to natural resource management [42]. Furthermore, traditional authorities in Ghana are not a single, homogenous institution, which has caused conflicts over land authority in some areas of Northern Ghana [43,44]. Traditional authority is typically divided between the traditional chief authority system, which is responsible for settling disputes in the communities, and the Tindaanas, or Earth Priests as they are also called in the literature more widely, whose role is to manage land and other natural resources $[17,44]$. The duties of the Tindaana and the chief overlap and vary amongst places, which can cause conflicts over resources [42,44]. The implementation of a CREMA to some extent aims to reduce conflicts resulting from these overlapping mandates, and in this case, to clarify who has authority over shea collection and sales.

Shea land formalization in this case takes place through the inscription of the traditional rules that are consistent with national laws, within a legally-binding document [14]. Traditional rules consist of punishments and taboos that are informal in the sense that they are not written down or legally backed by the state, but that are part of general knowledge in a given community. Formalization takes place through the inscription of some of these rules in by-laws enabled by the CREMA framework, which is recognized by the state. The CREMA by-laws prohibit for example to 'Indiscriminately fell trees ( ... ) Hunt, capture or destroy any animal in the CREMA ( . . . ) Collect any other/commercial NTFPs from the CREMA except with the consent of the CREMA Executive Committee (CEC)' (Murugu-Mognori CREMA, 2010). According to a youth leader in Murugu, the by-laws do not differ from the regulations of the Tindaana (Youth leader, Interview on 22 September 2017). Homogenizing law and tradition through the CREMA by-laws aims to better control natural resource use. One CREMA member, for example, explained: 'we have our local laws of punishment. When we apply our punishment to you, and you refuse it, then we have a chance to pass it over to the government.' (Murugu, interview on 14 September 2017). Traditional authorities have been, therefore, crucial to the process of shea land formalization via the CREMA, as has an environmental NGO that has been key to translating the added value of the CREMA to beneficiary communities. We develop these encounters and demonstrate the role of these brokers in gatekeeping the benefits of market-based conservation in the following sections.

\subsection{Beyond a Market Logic: Contrasting Narratives of CREMA Legitimation}

People living in communities around Mole National Park had been hunters for many generations. However, their activities were made illegal within the boundaries of the Mole National Park: hunters became poachers after the park was created. Poaching and logging were still identified as problematic activities in a report from the NGO that helped to implement the CREMA in 2007. This was also confirmed by employees of that NGO, of Mole National Park, and by a governmental official. The employee of the NGO argued that Kaden's interest in illegal activities, like poaching and logging, led to their rejection of the CREMA. It implied that Kaden likes to rebel, and that it does not want to establish a CREMA because it is not interested in more regulations on resource use, and, by extension, for conservation. This argument was also voiced by Wildlife Division staff in a NGO project meeting, in the capital Accra, at the time of the study. A NGO officer, for example, argued:

'This decision [to reject the CREMA] was mainly due to the fact that they felt they [residents of Kaden] would be restricted not to do a lot of the illegal activities they are used to. (... ) They 
wholly welcome these illegal activities. Therefore, their decision wasn't surprising at all.' (NGO officer, questionnaire, 12 December 2017).

Unsurprisingly, this narrative contrasts starkly with the way people in Kaden justify their own rejection of the CREMA. Through the establishment of Mole National Park, residents of Kaden perceive that they lost authority over, and access to their land, to hunting grounds and sacred places [38]. The way the rejection of the CREMA was justified in interviews in Kaden is related to the history of the village with Mole National Park. Interviewees expressed fears that the CREMA replicates the story of the Park creation, and related evictions, and these fears were used as a way to explain why people were not willing to accept the CREMA. The memories of Mole National Park evictions are still alive, and as an ex-NGO field officer stated 'they [Kaden] don't trust the government' (Damongo, interview, 18 October 2017). A quote of Kaden's Tindaana (earth priest) reflects these fears:

'When the CREMA people came, they said we should cut a place for them and we asked them, if we give them the place, can the women go there to pick the shea nuts? They said: No. Can the men go to farm? They said: No. We said: If it is like that, we don't accept.' (Tindaana, Kaden, interview, 13 October 2017).

For the people interviewed in Kaden, all these restrictions seemed to be very similar to the ways in which Mole Reserve was first established, and the chief in Kaden stressed that he did not want to be the one who gives away land again (Chief, Kaden, interview, 6 October 2017). The fear of losing autonomy and giving away more land, is reflected in another quote: 'when we give the land to them, there will not be sufficient food for us' (man, Kaden, interview, 5 October 2017). They did not want the government or a NGO to interfere in their resource regulations. They already lost land once; they did not want to make the same mistake a second time.

Murugu was in a similar position as Kaden. It was not displaced when Mole Reserve was created, but it lost farm land, hunting grounds, and sacred areas [38]; nonetheless it accepted the CREMA. The narrative around Murugu's acceptance is that its resentment from the past could be transformed: the community understood the advantages of forming a CREMA and so accepted it. In 1995, a participatory study conducted in the communities surrounding the Mole National Park illustrates this:

'We were able to move beyond the frustrations by asking the village elders to narrate the history of the village and the history of relations with the department through the creation of the reserve and its on-going management $(\ldots)$. Following that visit Murugu became the most open and trusting of the park villages.' [38].

Interviews in Murugu confirm this narrative. One man further explained that at the time of the Reserve creation in 1958, the traditional authorities agreed to give land to create the park, which made people in Murugu afraid of the repercussions of establishing a CREMA (male informant, Murugu, interview, 21 September 2017). The interviews further indicate that when the CREMA was proposed, staff from the NGO, the National Park and the Wildlife Department informed people in Murugu about the CREMA and its advantages, which led people in Murugu to accept it. One man in Murugu, for example, explained: 'They were fully engaged, continuously, they came in to tell us about the concept of the CREMA, and we got to understand the whole thing' (man, Murugu, interview, 21 September 2017). The Murugu-Mognori CREMA has, since then, been regarded as exemplary (email questionnaire, Mole National park official, 6 November 2017), and the narrative about Murugu's acceptance is that the residents managed to heal from the wounds from the creation of Mole National Park.

Murugu is presented as a model that can act as an incentive to convince Kaden to join the CREMA in the future. The added economic benefits achieved from the trade of certified organic shea in CREMA communities is expected to attract other, more reluctant communities, to join the CREMA approach. The Operations Manager from the company that traded shea with collectors in Murugu indeed suggested in one interview: 
'So, let's see how we can encourage them [Kaden] to sign on to the conservation program before we allow them also to benefit from things that are coming out of conservation.' (Company, Operations manager, Tamale, interview, 24 October 2017).

This illustrates the hope that the economic results achieved in Murugu would motivate Kaden to join the project in the future, and put the past behind as Murugu had seemingly done.

There is no doubt that there are more complex, historical reasons than those presented above for one community to accept the CREMA and the other not. Rather than drawing out one single 'truth' to the story, we are interested in patterns of truth that emerge from interviews. The patterns presented above emphasize the importance of historical relations between state and society. Market-based approaches to conservation largely rely on the economic rationality of those involved-in this case it is assumed by those promoting access to the certified shea market that the added benefits from certified shea trade will draw people to participate in conservation schemes. Here, however, we see that this market logic is far less important in drawing people towards market-based conservation than state-society historical relations of land distribution and access. Below we show, however, that is it is not state officials but rather non-state ones that broker and mediate who is able to benefit from shea land formalization.

\subsection{Traditional Authorities and NGOs Producing the Winners and Losers of Shea Land Formalisation}

In this section, we interrogate the implications of the respective decisions to accept and reject the CREMA for shea collectors, and we highlight the role of broker institutions, specifically the NGO and traditional authorities, in brokering access to CREMA benefits. Connecting female collectors with a company that trades certified organic shea nuts in the CREMA aimed to improve income from natural resource production, and women in Murugu obtained higher returns from the sale of shea nuts to the company than those in Kaden. In Murugu, we therefore expected collectors to feel empowered from the connection to certified shea nut markets, however the women described these increased benefits as marginal. Conversely, in Kaden, we expected residents to feel empowered since they rejected the CREMA, but women and some young men actually explained that they felt left out of potential CREMA benefits. We argue that these surprising perspectives can be better understood by examining the role played by 'access gatekeepers', namely NGOs and traditional authorities, in brokering land formalization in each case, starting with that of Murugu.

\subsubsection{Improving Shea Benefits in Murugu}

NGOs often assist a given community to develop a CREMA, but like other integrated conservation and development projects [45], CREMA is still a top-down approach with paternalistic undertones. Although the NGO does not define the resource regulations inscribed in the by-laws of a CREMA, its objectives can be influenced by the NGO. The NGO's facilitating role in the development of regulations is a powerful one. The communities are also dependent on the NGOs' knowledge and networks to develop the CREMA, and the community-NGO relationship sometimes comes across as being similar to a parent-child relationship, as described by a member of the CREMA Executive Committee:

'The NGO is a start of the concept. If you give birth to a new born baby, you will eventually teach it how to sit, how to crawl, how to walk. When the child starts walking, then it is a bit matured. Soon it will do his or her walking without your help. So, we are still under them, to give us the support. When we get on our toes fully, we can operate on our own, without a NGO.' (CREMA Executive Committee member, Murugu, interview on 14 September 17).

This does not mean that communities do not have agency within this process, as the case of Kaden demonstrates [46], but does mean that NGOs can select whom to support and whom to exclude [47]. They are able to choose which community gets the opportunity to be empowered and how they become so. This is well illustrated in the perceptions of women about the added value of their connections with the certified organic shea markets. 
In Murugu, we expected the beneficiaries of the project to feel empowered from it, but interrogating perceptions showed a more nuanced picture. As seen before, women are traditionally only marginally involved in political decision-making regarding natural resource management in northern Ghana [48], and the CREMA and shea certification in Murugu aimed to counteract gender inequalities. This is clear from the slogan of the company that states: 'Empowering Ghanaian Women through Shea Butter'. A staff member from the company further explained that: 'It is business, doing the certification with the women, but it is also empowerment.' (Company, Operations manager, Tamale, interview, 24 October 2017).

The certified trade in Murugu includes formal contracts between the company and female collectors, quality standards, and predefined price per quantity (nuts are weighed before selling). Outside the CREMA, collectors do not have a formal trade relationship with the middlemen or female traders. They are not bound to one specific trader, and the price is negotiated between them without weighing the nuts and without a formal contract. Within the CREMA, women sign a contract with the company that binds them to 'not take nuts from non-registered collectors and sell them to [the company]' (Company n.d.). The CREMA allows the company to become another, albeit exclusive, middleman in the shea trade.

Women have been empowered through the added economic value from trading within the certified organic shea market. A CREMA committee member said that women participate actively and not only passively as was feared, because of the gendered power structure:

'They [women] knew within themselves that they should be part of decision making, but in the past, when women were invited into decision making, they were quiet, they would not say anything. (... ). There was a fear and belief that women are to accept, whatever the man says. Now they are beginning to understand that they also have the right to contribute and that their contribution can be accepted.' (man, Murugu, interview on 21 September 2017).

Different interviewed women stated that the certification project recognized them as shea producers, which made them feel proud, and indeed confident in their rights. An anecdote from the field illustrates this whereby one day, during the fieldwork, women criticized the company buying nuts just like the previous middlemen, without weighing and handing out of correct receipts:

'We thought that it [selling nuts to the company] would be different from how the middlemen buy it. When they came, they said they will weigh the shea nuts. But now, they are not weighting, and they are buying the same way as the middlemen. There is not any difference.' (Organic shea collector 5, female, Murugu, interview on 13 October 2017).

When this critique emerged, the CREMA Executive Committee immediately took responsibility and organized a meeting with the company. A field officer from the company apologized for the incorrect way in which the nut trade had been conducted, and promised to purchase the nuts in the future, according to the way it was defined in the contract. This incident shows that women were able to raise their voice and were confident that they could claim their rights.

On the other hand, the added value of the project seemed to be too marginal to lead effectively to female empowerment. The general expectation underlying the CREMA connection with certified shea markets is that a higher income from certified shea nuts automatically empowers women, but interviews with female collectors in Murugu challenge this expectation. Interviewees explained that the additional income did not make a significant difference in their livelihood opportunities, which meant that they used the marginally higher income to pay for regular expenses such as, 'to buy ingredients for the meals, for school fees and for health expenses.' (Woman, shea collector, Murugu, interview, 12 September 2017). It is undisputed that the additional income is urgently needed, but these statements show that the additional income from certification contracts is not sufficient for women to move beyond covering basic, gendered, expenditures in their lives.

So, the improvements for women within the CREMA have been marginal, but they have nonetheless been an improvement, and these have been achieved because the NGO was able to convince communities to engage shea land formalization through the CREMA. To situate this within 
the wider debate at hand here, we show that it is not the logic of economic profit maximization that makes market-based conservation work in this case $[9,10]$, but it rather takes place through the kinds of historical land relations that state and society have entertained, as they are mediated by the land formalization encounter between traditional authorities and the NGO. Understanding this encounter enhances our understanding of the conditions under which the benefits of market-based conservation are distributed. Below, we show that such encounters also occurred but took a different path in Kaden, where the CREMA was rejected.

\subsubsection{Exclusion from Organic Shea Benefits in Kaden}

In Kaden we expected residents to feel empowered since the formalization of resource rules and trade was actively rejected, however this is not the perception of those interviewed in Kaden. Generational and gender hierarchies run deep, and elder men are respected and powerful in Ghana, while women and younger men have to accept their decisions [49]. These generational and gender power relations shaped the rejection of CREMA in Kaden, and interviews with women and young men show that they could not influence these decisions regarding CREMA land formalization. A young man from Kaden explained this feeling of powerlessness, concerning the CREMA rejection when he stated that 'we the young men, are realizing, that our elders are cheating us, but we have nothing to say about it. We don't know what to do (... ) we are only waiting for our turn to come.' (man, Kaden, interview on 5 October 2017).

The same sense of subordination emerged in interviews with women in Kaden. One woman, the leader of the woman's group, described figuratively her powerlessness regarding the CREMA decision: 'you are willing to give the book to me and my father says, I shouldn't collect the book. Can I collect it?' (Magazia, shea collector, Kaden, interview on 5 October 2017). With this metaphor, this woman meant that even if she had wanted the CREMA, she felt like she had to accept the traditional authorities' decision. In Kaden the rejection of the CREMA by traditional authorities meant that women were automatically excluded from the better paid certified shea market, since the company is only active in CREMA communities.

'The NGO mentioned that, as long as they [Kaden] are not willing to sign on to the CREMA management, they should also not benefit from anything that comes because of the CREMA. So, it is something that is like a control.' (Company, operations manager, Tamale, interview, 24 October 2017).

Another company staff member explained that the company would have been interested in buying nuts from Kaden for logistical and quantity reasons. However, because it was not partnering with the NGO, they remained loyal and supported the NGO's view: 'If I would go there to buy nuts, it would be somehow a betrayal to the partner [NGO].' (Company, Field officer, Murugu, interview, 14 October 2017). As the activities of the company in the Mole area coincide with the surface area of the CREMA, this segregates Murugu's and Kaden's respective abilities to benefit from engaging the certified nuts market.

The rejection of traditional authorities to agree to form a CREMA has implications that go beyond the specific CREMA initiative. An interviewee in Kaden for example complained that NGOs generally do not come to Kaden anymore: 'NGOs either go to Yazori or Murugu, help will not come here [to Kaden]. That means we are losing.' (male informant, Kaden, interview on 5 October 2017). From the perspective of the NGO, their non-engagement with Kaden is legitimate, as Kaden was not cooperative. An ex-field officer explained the exclusion by Kaden's dismissive attitude: 'I don't even stop there [in Kaden], because, I don't have enough time to waste on places that I know won't cooperate.' (ex-NGO field officer, Damongo, interview on 18 October 2017). The rejection of the CREMA in Kaden could be celebrated as a feat of empowerment, but the community also 'said no' to development [50]. This is now seen by many as a loss: many services are coordinated through NGOs, which are part of a tight network of service providers who choose the communities with which they work. This gatekeeping process has been key to the conditions under which access to shea takes place in the study area. 
Husseini et al. [51] also describe that the exclusion of women in the management of forest reserves in Ghana was legitimated by traditional gender roles. In Kaden, women generally argued that the CREMA is about forest and land matters and therefore part of men's responsibilities: 'Women don't know about forest/bush matters' (shea collector, Kaden, interview, 6 October 2017). Another one explained: 'we are women; we cannot talk about the CREMA. We are just there to marry, but not to focus on such things' (shea collector, Kaden, group discussion, 27 October 2017). Although it aimed to empower women, talks about shea land formalization under the CREMA model has brought the business of women-organized shea collection into that of land and politics, a domain that is traditionally overseen by men and traditional authorities [24,52].

Here we have shown that uneven access to certified shea takes place under this form of market-based conservation, through the negotiated encounter of NGOs and traditional authorities. Participating in this form of conservation does not follow an open market logic: individual women cannot choose to freely engage in the market of certified nuts. Their engagement in this market depends on brokers, such as traditional authorities, who make the decision to accept or reject a CREMA project, and a NGO that choose which communities should benefit from certified nuts and which ones should not. Here we have shown that land formalization has been a key moment during which these dynamics occur.

\section{Conclusions}

Community-Based Natural Resource Management was initiated in many places to improve the use of natural resources through participatory methods [1], and in the search for a 'reconciliation between conservation and livelihoods', market-based conservation approaches have emerged [7]. The case we discuss here, combining the CREMA model in Ghana with the connection to certified organic shea trade, illustrates such a market-based approach to conservation, and we have specifically been concerned with understanding how the benefits of such an approach become distributed in the case study area, between different communities.

In much of the literature on market-based conservation, the focus has been on the retreat of the state and the creation of new markets (e.g., for so-called Payments for Ecosystem Services, and for carbon) and this raises questions about the new role that the state assumes within this trend. In this paper we focus on the role of the state as a distributor of property rights, and specifically on the process of land formalization, which appears to be key to articulating conservation and trade objectives, especially in postcolonial contexts where much governance takes place informally [53,54]. As we show here, many institutions are however involved in the process of shea land formalization (traditional authorities, NGOs, state), and these do not inter-relate on a historical blank slate. Rather than the economic profit maximization appeal that underlies a market-based conservation logic, these historical land relations, as they occur in the brokering of shea land formalization, influenced the conditions under which benefits from the certified organic shea market could occur or not.

This paper unpacked the power relations between the different actors involved in the certification and formalization process and showed how, during the brokering of shea land formalization, winners and losers are produced. The different narratives of legitimation that we analyzed illustrate the importance of past state-society relations in mediating the conditions under which market-based conservation takes place, or not, and the role that land formalization brokers play in to rehearsing these histories. In Kaden, the decision to not join the CREMA project was influenced by the tense historical relations with the state, after the creation of Mole National Park. Traditional authorities feared that history would repeat itself, through a CREMA as a National Park dressed up in new clothes. NGO and park officials presented this rejection as a function of Kaden residents' engagement in illegal poaching and logging activities. The CREMA-acceptance in Murugu, on the other hand, was explained through the recovery of trust in the government: Murugu could heal from the wounds sustained from the establishment of Mole National Park. In the latter community, female shea collectors benefitted 
economically, if only marginally, to the connection that the CREMA enabled with certified organic global shea markets, whereas in Kaden they did not.

We would like to conclude by addressing conservationists and by highlighting that granting access to the global market is a powerful instrument used in market-based conservation, which should be implemented with care. In this case study, certification has been tied to the CREMA and with it to the shea land formalization process. The condition to be part of the CREMA in order to certify shea nuts, constructed a barrier for shea collectors to enter the certified market. Brokers (in this case, a NGO and traditional authorities) play a powerful role in gate-keeping access to these markets. This case points out that access is not only tied to finance, technology and information [55] but also to the politics of resource management. Research has shown that the success of CBNRM projects is firstly, dependent on understanding the complexity and diversity of and the power relations within communities [56]. Secondly, taking into account historical relations with the government, including appropriation of community natural resources by the state is key [57]. Thirdly, in order to build up a functioning CBNRM initiative and reduce inequalities within it, a common understanding of different rationales that underlie motivations on how to use and regulate access to natural resources need to be considered [56]. Almost 20 years after conservationists have pointed out the importance of 'good-neighborhood policies' with local communities and in relating resource rights to the certification of NTFPs for conservation [55], we see that the socio-historical politics of land formalization underlying certification programs still require attention.

Author Contributions: Conceptualization, M.G., M.C., and G.W.; methodology, M.G., M.C., and G.W.; validation, M.G., M.C., and G.W.; formal analysis, M.G., M.C., and G.W.; investigation, M.G.; data curation, M.G.; writing-original draft preparation, M.G., M.C., and G.W.; writing-review and editing, M.G., M.C., and G.W.; supervision, M.C. and G.W.; project administration, M.G.; funding acquisition, M.G., M.C., and G.W. All authors have read and agreed to the published version of the manuscript.

Funding: The fieldwork was financially supported by the Political Geography Unit, at the University of Zurich. The publishing costs were covered by the University of Lausanne. Other than that, this research did not receive any specific grant from funding agencies in the public, commercial, or not-for-profit sectors.

Acknowledgments: The authors thank the community members from Murugu and Kaden, who contributed their time to this work. We also thank representatives from the Murugu-Mognori CREMA, the NGOs which provided first access to the study site, the shea company, the Mole National Park and the Wildlife Division of Ghana for their contribution. We also thank the anonymous reviewers who gave comments to improve the manuscript.

Conflicts of Interest: The authors declare no conflict of interest. The funders had no role in the design of the study; in the collection, analyses, or interpretation of data; in the writing of the manuscript, or in the decision to publish the results.

\section{References}

1. Roe, D. Community Management of Natural Resources in Africa: Impacts, Experiences and Future Directions; IIED: London, UK, 2009; ISBN 978-1-84369-755-8.

2. Agrawal, A.; Gibson, C.C. Enchantment and disenchantment: The role of community in natural resource conservation. World Dev. 1999, 27, 629-649. [CrossRef]

3. Baruah, M. Effect of Institutional Choices on Representation in a Community Resource Management Area in Ghana; Responsive Forest Governance Initiative Working Paper Series; Murombedzi, J., Ribot, J., Walters, G., Eds.; IUCN, University of Illinois, and the Council for the Development of Social Science Research in Africa (CODESRIA): Dakar, Senegal, 2015.

4. Baruah, M. Facipulation and elite formation: Community resource management in Southwestern Ghana. Conserv. Soc. 2017, 15, 371-383. [CrossRef]

5. Brechin, S.R. Contested Nature: Promoting International Biodiversity with Social Justice in the Twenty-First Century; State University of New York Press: Albany, NY, USA, 2003; ISBN 978-0-7914-5775-7.

6. Shanley, P. Tapping the Green Market: Certification and Management of Non-Timber Forest Products; People and Plants Conservation Series; Earthscan: London, UK; Sterling, VA, USA, 2002; ISBN 978-1-85383-871-2.

7. Roth, R.J.; Dressler, W. Market-oriented conservation governance: The particularities of place. Geoforum 2012, 43, 363-366. [CrossRef] 
8. Hall, D.; Hirsch, P.; Li, T. Powers of Exclusion: Land Dilemmas in Southeast. Asia; University of Hawai Press: Honolulu, HI, USA, 2011; ISBN 978-0-8248-3603-0.

9. Heynen, N. (Ed.) Neoliberal Environments: False Promises and Unnatural Consequences; Routledge: London, UK; New York, NY, USA, 2007; ISBN 978-0-415-77148-1.

10. Fletcher, R. Neoliberal environmentality: Towards a poststructuralist political ecology of the conservation debate. Conserv. Soc. 2010, 8, 171. [CrossRef]

11. Asare, R.A.; Kyei, A.; Mason, J.J. The community resource management area mechanism: A strategy to manage African forest resources for REDD+. Philos. Trans. R. Soc. B Biol. Sci. 2013, 368, 20120311. [CrossRef]

12. Wardell, D.A.; Lund, C. Governing access to forests in northern Ghana micropolitics and the rents of non-enforcement. World Dev. 2006, 34, 1887-1906. [CrossRef]

13. Acquah, E.; Dearden, P.; Rollins, R. Nature-based tourism in Mole National Park, Ghana. Afr. Geogr. Rev. 2016, 35, 53-69. [CrossRef]

14. Dzekoto, G.E.; Bosu, D. Community resource management areas (CREMAs) in Ghana: A promising framework for community-based conservation. In World Heritage for Sustainable Development in Africa; Moukala, E., Odiaua, I., Eds.; UNESCO: Paris, France, 2018; pp. 37-43.

15. Wardell, A.; Fold, N. Globalisations in a nutshell: Historical perspectives on the changing governance of the shea commodity chain in northern Ghana. Int. J. Commons 2013, 7, 367. [CrossRef]

16. Chalfin, B. Shea Butter Republic: State Power, Global Markets, and the Making of an Indigenous Commodity; Routledge: New York, NY, USA, 2004; ISBN 978-0-415-94460-1.

17. Rousseau, K. Political Ecology du Karité: Relations de Pouvoir et Changements Sociaux et Environnementaux Liés à la Mondialisation du Commerce des Amandes de Karité Cas de l'Ouest du Burkina Faso; ParisTech: Paris, France, 2016.

18. Poudyal, M. Tree Tenure in Agroforestry Parklands: Implications for the Management, Utilisation and Ecology of Shea and Locust Bean Trees in Northern Ghana; University of York: York, UK, 2009.

19. Shepherd, G. Opportunities for Interventions around Mole National Park which both Enhance Livelihoods and Promote REDD+ Agendas; International Union for Conservation of Nature and A Rocha: Accra, Ghana, 2016.

20. Lovett, P.N. The shea butter value chain: Production, transformation and marketing in West Africa. West. Afr. Trade Hub Tech. Rep. USAID 2004, 2, 1-40.

21. Olivier de Sardan, J.-P.; Bierschenk, T. Les courtiers locaux du développement. Bull. L'APAD 1993. [CrossRef]

22. Mosse, D.; Lewis, D. Theoretical approaches to brokerage and translation in development. In Development Brokers and Translators: The Ethnography of Aid and Agencies; Lewis, D., Mosse, D., Eds.; Kumarian Press Inc.: West Hartford, CT, USA, 2006; pp. 1-26.

23. Büscher, B.; Fletcher, R. The Conservation Revolution: Radical Ideas for Saving Nature Beyond the Anthropocene; Verso: London, UK; New York, NY, USA, 2020; ISBN 978-1-78873-770-8.

24. Elias, M.; Arora-Jonsson, S. Negotiating across difference: Gendered exclusions and cooperation in the shea value chain. Environ. Plan. D 2017, 35, 107-125. [CrossRef]

25. Nightingale, A.J. Bounding difference: Intersectionality and the material production of gender, caste, class and environment in Nepal. Geoforum 2011, 42, 153-162. [CrossRef]

26. Omoding, J.; Walters, G.; Andama, R.; Carvalho, S.; Colomer, J.; Cracco, M.; Eilu, G.; Gaster Kiyingi, K.; Kumar, C.; Langoya, C.D.; et al. Analysing and Applying Stakeholder Perceptions to Improve Protected Area Governance in Ugandan Conservation Landscapes. Land 2020, 9, 207. [CrossRef]

27. Bolwig, S.; Ponte, S.; Du Toit, A.; Riisgaard, L.; Halberg, N. Integrating Poverty and Environmental Concerns into Value-Chain Analysis: A Conceptual Framework. Dev. Policy Rev. 2010, 28, 173-194. [CrossRef]

28. Berg, L.D.; Kitchin, R.; Thrift, N. Discourse analysis. In International Encyclopedia of Human Geography; Elselvier: Oxford, UK, 2009; pp. 215-221.

29. Okoro, J.A. Reflections on the Oral Traditions of the Nterapo of the Salaga Area. Hist. Afr. 2008, 35, 375-400. [CrossRef]

30. Kwaku Brukum, N.J. The Northern Territories of the Gold Coast under British Colonial Rule, 1897-1956: A study in Political Change; University of Toronto: Toronto, ON, Canada, 1997.

31. Haight, B.M. Bole and Gonja Contributions to the History of Northern Ghana; Northwestern University: Evanston, IL, USA, 1981.

32. Sobey, D.G. Anogeissus groves on abandoned village sites in the Mole National Park, Ghana. Biotropica 1978, 10,87-99. [CrossRef] 
33. Grischow, J.D. Late colonial development in British West Africa: The Gonja development project in the Northern territories of the Gold Coast, 1948-57. Can. J. Afr. Stud. Rev. Can. Études Afr. 2001, 35, 282-312. [CrossRef]

34. Wardell, A. Groundnuts and headwaters protection reserves. Tensions in colonial forest policy and practice in the Northern Territories of the Gold Coast. In Commonwealth Forest E Environmental History. Empire Forests and Colonial Environments in Africa, the Caribbean, South Asia and New Zealand; Damodan, V., D'Souza, R., Eds.; Primus Books: Delhi, India, 2020; pp. 357-401.

35. Robinson, L.W.; Sasu, K.A. The role of values in a community-based conservation initiative in Northern Ghana. Environ. Values 2013, 22, 647-664. [CrossRef]

36. Forestry Commission. Mole National Park Management Plan; Republic of Ghana: Accra, Ghana, 2011.

37. Acquah, E.; Rollins, R.; Dearden, P.; Murray, G. Concerns and benefits of park-adjacent communities in Northern Ghana: The case of Mole National Park. Int. J. Sustain. Dev. World Ecol. 2017, 24, 316-327. [CrossRef]

38. Mason, J.; Danso, E. PRA for people and parks: The case of Mole National Park, Ghana. PLA Notes 1995, 22, 76-79.

39. Nelson, F. Community Rights, Conservation and Contested Land: The Politics of Natural Resource Governance in Africa; Earthscan: London, UK; Washington, DC, USA, 2010; ISBN 978-1-84407-916-2.

40. Fabricius, C.; Koch, E.; Turner, S.; Magome, H. Rights, Resources and Rural Development: Community-Based Natural Resource Management in Southern Africa; Earthscan: London, UK; Sterling, VA, USA, 2004; ISBN 978-1-84407-010-7.

41. Adjei, P.O.-W.; Agyei, F.K.; Adjei, J.O. Decentralized forest governance and community representation outcomes: Analysis of the modified taungya system in Ghana. Environ. Dev. Sustain. 2018. [CrossRef]

42. Lund, C. Who owns Bolgatonga? A story of inconclusive encounters. In Land and the Politics of Belonging in West Africa; Kuba, R., Lentz, C., Eds.; Brill Academic Publishers, Incorporated: Leiden, The Netherlands, 2006; pp. 77-98.

43. Berry, S. No Condition is Permanent: The Social Dynamics of Agrarian Change in Sub-Saharan Africa; University of Wisconsin Press: Madison, WI, USA, 1993.

44. Ubink, J.M.; Amanor, K. Contesting Land and Custom in Ghana: State, Chief and the Citizen; Law, Governance, and Development Research; Leiden Univ. Press: Leiden, The Netherlands, 2008; ISBN 978-90-8728-047-5.

45. Wells, M.P.; McShane, T.O.; Dublin, H.; O'Conner, S.; Redford, K.H. The future of integrated conservation and development projects: Building on what works. In Getting Biodiversity Projects to Work: Towards More Effective Conservation and Development; McShane, T.O., Wells, M.P., Eds.; Columbia University Press: New York, NY, USA, 2004.

46. Holmes, G. Conservation Jujutsu, or how conservation NGOs use market forces to save nature from markets in Southern Chile. In The Anthropology of conservation NGOs; Larsen, P., Brockington, D., Eds.; Palgrave Macmillan: London, UK, 2018; pp. 181-202.

47. Ribot, J.C.; Chhatre, A.; Lankina, T. Introduction: Institutional choice and recognition in the formation and consolidation of local democracy. Conserv. Soc. 2008, 6, 1-11.

48. Apusigah, A.A. The gendered politics of farm household production and the shaping of women's livelihoods in Northern Ghana. Fem. Afr. 2009, 12, 51-68.

49. Evans, R.; Mariwah, S.; Barima Antwi, K. Struggles over family land? Tree crops, land and labour in Ghana's Brong-Ahafo region. Geoforum 2015, 67, 24-35. [CrossRef]

50. De Wet, J.P. 'We don't want your development!': Resistance to imposed development in Northeastern Pondoland. In Rural Resistance in South Africa: The Mpondo Revolts after Fifty Years; Kepe, T., Ntsebeza, L., Eds.; Brill: Leiden, The Netherlands, 2011; pp. 259-278.

51. Husseini, R.; Kendie, S.B.; Agbesinyale, P. Community participation in the management of forest reserves in the Northern Region of Ghana. Int. J. Sustain. Dev. World Ecol. 2016, 23, 245-256. [CrossRef]

52. Rousseau, K.; Gautier, D.; Wardell, D.A. Renegotiating access to shea trees in Burkina Faso: Challenging power relationships associated with demographic shifts and globalized trade: Renegotiating access to shea trees in Burkina Faso. Agrar. Chang. 2017, 17, 497-517. [CrossRef]

53. Peluso, N.L.; Lund, C. New frontiers of land control: Introduction. J. Peasant Stud. 2011, 38, 667-681. [CrossRef] 
54. Putzel, L.; Kelly, A.B.; Cerutti, P.O.; Artati, Y. Formalization as development in land and natural resource policy. Soc. Nat. Resour. 2015, 28, 453-472. [CrossRef]

55. Pierce, A.R. Social issues. In Tapping the Green Market: Certification and Management of Non-Timber Forest Products; Laird, S.A., Guillen, A., Pierce, A.R., Eds.; Earthscan: London, UK, 2002; pp. 283-298.

56. Dekker, L.A.; Arts, K.; Turnhout, E. From rationalities to practices: Understanding unintended consequences of CBNRM. Conserv. Soc. 2020, 18, 137. [CrossRef]

57. Blaikie, P. Is small really beautiful? Community-based natural resource management in Malawi and Botswana. World Dev. 2006, 34, 1942-1957. [CrossRef]

(C) 2020 by the authors. Licensee MDPI, Basel, Switzerland. This article is an open access article distributed under the terms and conditions of the Creative Commons Attribution (CC BY) license (http://creativecommons.org/licenses/by/4.0/). 